logos_i_ethos_2018_2_(48), s. 31-51

DOI: http://dx.doi.org/10.15633/lie.2784

Karol Jasiński

https://orcid.org/0000-0002-7695-499X

University of Warmia and Mazury in Olsztyn

The Problem of Political Religion

For many centuries, the relationship between politics and religion has continued to arouse interest not only among active participants of socio-political life, but also representatives of religious institutions. In this context, politics is generally

Karol Jasiński - presbyter of the Warmian Archdiocese; habilitated doctor in the humanities in the field of philosophy; researcher and teacher at the Faculty of Theology of the University of Warmia and Mazury in Olsztyn; interests: philosophy of religion and social philosophy. regarded as the art of gaining power and ruling a country, while religion is considered a system of beliefs and practices cultivated by a group or an individual with regard to the (variously understood) sacred. The relationship between those two crucial spheres of human activity may take up different forms: the supremacy of religion over politics, the supremacy of politics over religion, their separation, or their cooperation. In some extreme cases, the relationship leads to the emergence of a political religion.

The notion of political religion, relating to the situation when politics is placed in the service of religion or vice versa, was first used in $17^{\text {th }}$ century Europe by George Thomson, Tommaso Campanella and Daniel Clasen. In the $20^{\text {th }}$ century, it served Eric Voegelin and Raymond Aron to establish the concept of totalitarian regimes. According to Voegelin and Aron, political religion - as a secular phenomenon which preserves the religious structure and its inner-worldly content - was brought about by secularisation, political exploitation of certain elements of religion, elevation of the secular authority to the level of religious power and the search for salvation through politics. It is the product of the separation 
the state from any transcendence and a manifestation of political ideologies of the $20^{\text {th }}$ century. ${ }^{1}$ Political religion is related to the so-called "false immanentization," or the separation of religious symbols from the fulfilling transcendental experience and their transfer to the realm of political institutions of a purely mundane character. ${ }^{2}$

In Poland, the issue of political religion was explored by Józef Tischner, who describes it as a form of perverted faith. The perversion manifests itself in the confusion between religion and politics, which impedes the dialogic communication of the faith. Politicians turn to religious texts and institutions in order to exploit religion. They use the idea of God for their own political gain. When faith becomes a political tool, its spiritual dimension is lost. Thus, political religion changes the meaning of faith. ${ }^{3}$

In the light of the above, the fundamental problem of political religion may be articulated as follows: it betrays its own nature and forgoes its fundamental spiritual and saving function, focusing instead on substitute functions with special emphasis on politics.

The temptation to use religion for political purposes is not foreign to many contemporary representatives of a multitude of political factions and groups. Driven by their short-term goals, politicians are unable or unwilling to notice the far-reaching consequences of their actions. As a result, apart from creating confusion between the spheres of church and state, they precipitate a perversion and a crisis of the religion itself.

The analysis presented below attempts to accomplish two goals: firstly, to reveal the nature and the function of religion, and secondly, to identify some of the threats resulting from its politicisation and basic ways of preventing the emergence of a political religion. The notion will be construed, in imitation of the $17^{\text {th }}$-century scholars, as an instance of placing politics in the service of religion or vice versa.

1 Cf. H. O. Seitschek, Mesjanizm polityczny i religia polityczna - niemieckie interpretacje uniwersalnego zjawiska, tłum. M. Kurkowska, „Teologia Polityczna” 4 (2006-2007), p. 96-103; J. Tischner, W krainie schorowanej wyobraźni, Kraków 1998, p. 47.

${ }^{2}$ Cf. Religia polityczna, http://www.newsweek.pl/europa/religia-polityczna,45280,1,1.html (2.12.2017).

3 Cf. J. Tischner, Nieszczęsny dar wolności, Kraków 1996, p. 174, 176-177, 188, 193. 


\section{What is religion?}

Religion is a complex phenomenon. According to estimates, as many as ten thousand various religions and creeds may exist in the world nowadays.

According to Paul Tillich, a German philosopher and theologian, religion occurs when man is grasped by some "ultimate concern" which makes the entire reality appear temporary and holds the answer to the question about the meaning of human life. ${ }^{4}$

However, an etymological consideration of the word may reveal that religion is concerned primarily with the establishment of a relationship between man and the Absolute. Such a relationship would translate into individual spiritual experiences, a doctrine, a worship and a community of the faithful. ${ }^{5}$

Thus, every religion is grounded in the experience of the transcendental dimension of the world. Throughout his existence and in all his actions, man is related to a being that transcends the entire reality. Openness to that supernatural being (the transcendent, sacrum, God) is a crucial part of human life and morality. ${ }^{6}$

In this context, Tillich emphasises the significance of faith as the highest concern of man, an act engaging the entirety of the human personality. It is central to the personal existence and embraces its every element. Faith is the most integrating action of man. It unites and affects all its parts and functions. Thus, it constitutes a total act which reorients the entire life of man and his understanding of the world. ${ }^{7}$

Thus, we ought to make every effort to preserve the identity and the fundamental mission of religion, which should give priority to the question about God. Religion should: let man experience faith, continuously revive faith, create the spiritual substance of life, and shape the moral awareness of man. It is the assistance provided in this area, rather than

4 Cf. P. Tillich, Pytanie o Nieuwarunkowane. Pisma z filozofii religii, tłum. J. Zychowicz, Kraków 1994, p. 259.

5 Cf. Z. J. Zdybicka, Człowiek i religia. Zarys filozofii religii, Lublin 1993, p. 280-281, 359-368.

6 Cf. Z. J. Zdybicka, Religia i polityka, „Człowiek w Kulturze” 3 (1994), p. 119.

7 Cf. P. Tillich, Dynamika wiary, tłum. A. Szostkiewicz, Poznań 1987, p. 33. 
solving social problems and political involvement, that should be the primary concern of religion. To achieve this fundamental goal, religion should never directly impose any truths or behaviours on others but rather exert indirect influence by presenting a certain lifestyle. ${ }^{8}$

In the light of the above, Tischner emphasises the need for fostering religious thinking which, as reason seeks faith and faith seeks reason, leads to the discovery and the acceptance of the existential truth. ${ }^{9}$ Thus, religion is grounded, among other things, in the authority of a witness. However, it is also a form of authority itself. ${ }^{10}$ Consequently, the authority of religion is also limited to the initiation and the cultivation of the connection with the Absolute, as well as the formation of the moral dimension of human existence.

Yet religion must, and does, preserve its worldly presence, for it is the world that remains the object of its mission. In the light of their mutual influence, it would seem important to establish a "theology of meeting" between religion and the world. Due to the mission of the "otherworldly" religion, its relationship with the world will always be marked with a certain tension, which may lead to purification and reinforcement of religion. ${ }^{11}$

Ultimately, religion serves two functions in the world, both intimated even by the authors who studied the etymology of the term. Cicero derives the term from the Latin relegere (to reread), Lactantius from religare (to bind), and Augustine of Hippo from reeligere (to choose again). ${ }^{12}$ Thus, it may be inferred that religion should primarily assist man in rereading and reinterpreting his life in the transcendental perspective, establishing a relationship with the Absolute, as well as choosing God and, consequently, a certain lifestyle.

8 Cf. H. Juros, Kościół. Kultura. Europa, Lublin-Warszawa 1997, p. 106-107, 110-111, 123124, 263-264.

9 Cf. J. Tischner, Myślenie według wartości, Kraków 1982, p. 339, 342-348, 351, 358.

10 Cf. A. Giddens, Nowoczesność i tożsamość. „Ja” i społeczeństwo w epoce późnej nowoczesności, tłum. A. Szulżycka, Warszawa 2012, p. 260-262.

${ }^{11}$ Cf. M. Zawada, Wartości duchowe w kulturze postmoderny, in: Europa wspólnych wartości. Chrześcijańskie inspiracje w budowaniu zjednoczonej Europy, red. S. Zięba, Lublin 2004, p. 167-168.

12 Cf. Z. J. Zdybicka, Człowiek i religia, op. cit., p. 280. 
Some scholars indicate other functions. The list includes: humanisation of the world and protection of the dignity of man as a person (Zofia Jadwiga Zdybicka) ${ }^{13}$ bestowal of the human faculty to apprehend the infinite (Max Müller), integration of man in reference to the supernatural reality (Max Weber, John Dewey), protection of socially accepted values (William Kelley Wright), achievement of salvation (Emil Brunner), bestowal of meaning and a divine dimension on the incidental life (Mircea Eliade), incorporation in the most profound structure of reality (Anton Antweiler), elimination of existential contradictions (Jean Paul Sartre), the struggle with the ultimate life problems through beliefs and practices (John Milton Yinger), integration of a community around beliefs and practices (Emile Durkheim). ${ }^{14}$

Niklas Luhmann, a German sociologist who regards religion as a social subsystem, discerns its primary function and various secondary functions. Within the scope of its fundamental function, religion gives interpretation and meaning to different situations and provides certain salvific goods. The secondary functions may concern the economy, education, and politics. At times, the lack of effectiveness, the insignificance of influence exerted on people, and difficulties in serving its fundamental purpose may cause religion to orient itself to secondary functions. In such an event, the primary function is diminished, although it remains the determinant of the religion's identity. Consequently, the weakness of the fundamental function is compensated by social engagement. According to Luhmann, the transition from the primary function to the secondaries is a mark of secularisation. ${ }^{15}$ The phenomenon of political religion provides an excellent example of the domination of an secondary function over the fundamental one, which - in the light of the previous postulates of Luhmann - testifies to the weakness and the crisis of religion.

13 Cf. Z. J. Zdybicka, Religia i polityka, op. cit., p. 128.

14 Cf. Z. J. Zdybicka, Człowiek i religia, op. cit., p. 293-295.

15 Cf. N. Luhmann, Funkcja religii, tłum. D. Motak, Kraków 2007, p. 22-28, 35-40, 54, 219$233,252-261$. 
Polish sociologist Janusz Mariański emphasises that in a totalitarian regime, religion serves not only the strictly religious functions but also those of substitute character. Under democratic rule, such functions should be fulfilled by the institutions of civil society. Mariański notes that the renouncement of substitute functions is often regarded as a symptom of the declining authority of religion. However, it actually benefits both the civil society and the religion itself. This is because religion must strive to preserve its identity and protect itself from becoming an educational institution, an economic partner, or a rival in the political struggle. Above all, it needs to be the community of salvation, which shapes the moral character of people. Thus, religion in a community should serve primarily its proper saving functions, which include the proclamation of the word of God, the cultivation of liturgy, and the ministry. Other functions are merely a complement of the former. ${ }^{16}$

Jarosław Gowin, a Polish political scientist, adds that the fundamental purpose of religion is its prophetic activity, which involves: reminding of the moral principles, criticising erroneous solutions, caring for the disadvantaged, building a social consensus, educating people to active and responsible participation in the civil society. ${ }^{17}$ In his mind, religion serves a formative role by teaching the citizens to rationally use their freedom, to establish a connection with God and with others, to act for the common good. ${ }^{18}$ Thus, according to Gowin, the prophetic activity of religion should have a spiritual and a social dimension.

\section{Dangers of the politicisation of religion}

Religion as a relationship between man and the Absolute is subject to various threats. One of them is ideologisation, which finds its expression in the imposition of the truth by force and touting a recipe for

16 Cf. J. Mariański, Kościół katolicki w społeczeństwie obywatelskim. Refleksje socjologiczne, Lublin 1998, p. 22-23, 45-46, 117, 146-147, 161.

17 Cf. J. Gowin, Kościół po komunizmie, Kraków 1995, p. 63-64.

18 Cf. J. Gowin, Religia i ludzkie biedy. Ks. Tischnera spory z Kościołem, Kraków 2003, p. 140. 
an ideal socio-political regime. ${ }^{19}$ In religion, the temptation of ideologisation must be resisted, especially as the faithful are not the owners of the truth but only its depositaries. Furthermore, due to its supernatural and personal dimension, religious truth transcends all religious institutions and cannot be fully apprehended. It cannot be imposed by force, either, for it requires a free choice and a willing acceptance. ${ }^{20}$ Religious truth is also salvific. Therefore, it does not directly translate into any distinct model of social life and may be implemented in a variety of ways. ${ }^{21}$ The difference between religion and ideology should be emphasised since it helps distinguish a religious standpoint from a politically implicated ideological one. ${ }^{22}$

The most common form of ideologisation of religion is its politicisation which, ultimately, subjects religion to the rules of political struggle. Politicisation creates divisions among people, causes aggressive accusations and attacks against rivalling standpoints. Consequently, religious activity comes to allow violence. ${ }^{23}$ Furthermore, political interest starts to dominate over the ministerial concern. ${ }^{24}$

As a rule, politics involves a quest for power which has no place in religion. Furthermore, public authorities do not necessarily foster religious

19 Cf. M. Zięba, Ale nam się wydarzyło. O papieżu i Polsce, Kościele i świecie, Poznań 2013, p. 299; M. Zięba, Kłopot za kłopotem. Katolik w dryfującej Europie, Poznań 2015, p. 140-141; M. Zięba, Po szkodzie? Przed szkodą? O Polsce, kapitalizmie i kontemplacji, Kraków 1996, p. 108-109.

20 Cf. M. Zięba, Ale nam się wydarzyło..., op. cit., p. 380; M. Zięba, Demokracja $i$ antyewangelizacja: komentując nauczanie Jana Pawła II, Poznań 1997, p. 48-49; M. Zięba, Epoka Jana Pawła II. Zrozumieć niezwykły pontyfikat, Poznań-Kraków 2006, p. 70-71; M. Zięba, Kłopot za kłopotem..., op. cit., p. 35-36,142-143,172-177; M. Zięba, Kościół wobec liberalnej demokracji, in: M. Novak, A. Rauscher, M. Zięba, Chrześcijaństwo, demokracja, kapitalizm, tłum. W. Büchner, Poznań 1993, p. 131-132, 137-143; M. Zięba, Papieże i kapitalizm, Kraków 1998, p. 67-70; M. Zięba, Po szkodzie? Przed szkodą?..., op. cit., p. 88, 106-107.

21 Cf. M. Zięba, Ale nam się wydarzyło..., op. cit., p. 300-301,321; M. Zięba, Chrześcijanie, polityka, ekonomia: prawdy i kłamstwa, Kraków 2003, p. 66-67; M. Zięba, Kłopot za kłopotem..., op. cit., p. 173.

${ }^{22}$ Cf. M. Zięba, Epoka Jana Pawła II..., op. cit., p. 72-76; M. Zięba, Papieże i kapitalizm, op. cit., p. $186-187$.

${ }^{23}$ Cf. J. Gowin, Religia i ludzkie biedy..., op. cit., p. 33,138-139.

24 Cf. J. Tischner, Nieszczęsny dar wolności, op. cit., p. 176. 
values. ${ }^{25}$ Therefore, religious thinking differs from political thinking. In the framework of the latter, man refers to power and authority in order to cultivate certain values. Authority commands the truth, which is subject to instrumental use. ${ }^{26}$ As a result, any human relationship, including a religious relationship, has the marks of a power relationship. ${ }^{27}$

According to Tischner, a religion with ties to the authorities evolves into an expression of "morbid imagination." It becomes particular, ideological, condemning, emotional and grounded in practices. Eventually, its supernatural dimension is lost. ${ }^{28}$ Gowin emphasises that "a religion of morbid imagination" brings about politicisation. In the long run, this process undermines the authority of religion, and leads to the rejection of faith. ${ }^{29}$

In general, political religion may take up two forms: politics may be placed in the service of religion or religion may be used as a political tool. Nowadays, the latter form seems more widespread. However, let us consider the manifestations of both phenomena.

Firstly, politics may be placed in the service of religion. In this case, religious representatives apply political methods in a struggle for gaining a central place in the society and broadening their sphere of influence. ${ }^{30}$ As a result, they promote a distinct worldview with the use of the state apparatus. The promotion may take four basic forms: the state forces a religion on the citizens, the state creates and maintains social conditions for the acceptance of the promoted religion, the state sets forth legal regulations favouring a religion, and the authorities turn to their religious beliefs to seek a religious justification for their decisions. ${ }^{31}$

25 Cf. J. Tischner, Nieszczęsny dar wolności, op. cit., p. 126.

26 Cf. J. Tischner, Filozofia dramatu, Paryż 1990, p. 129-130.

27 Cf. J. Tischner, Spór o istnienie człowieka, Kraków 1998, p. 48.

28 Cf. J. Tischner, $W$ krainie schorowanej wyobraźni, op. cit., p. 10-11, 210.

29 Cf. J. Gowin, Religia i ludzkie biedy..., op. cit., p. 120-121, 137.

30 Cf. H. Juros, Kościół. Kultura. Europa, op. cit., p. 108.

${ }^{31}$ Cf. R. Prostak, Teista $w$ demoliberalnym świecie. Rzecz o amerykańskich rozważaniach wokót rozumnej polityki, Kraków 2014, p. 42-43. 
This form of political religion has a specific understanding of human freedom. Freedom is real when subjected to objective criteria, and religion provides man with meticulous instructions for all imaginable life situations. Religion comes to resemble totalitarianism which knows an objective truth and tries to impose it on people by force, stripping them of privacy and ignoring their beliefs. The rule of religion is often enforced through ethics. Ethical rules are an extension of the religious precepts, whereas state laws are an extension of the ethical rules. ${ }^{32}$

Partisans of political religion of this type aspire to hold political power only to expand their own institutions and structures, which is their sole interest in the matter. As a result, the religious mission becomes political, the state becomes clerical, religious representatives are regarded merely as the members of the new political establishment, and the progressing institutionalisation impedes the development of close relationships with people. The concern for institutional growth testifies to the weakness of religion. A solely institutional presence of religion in society is an improper form of its existence. In addition, an institutionalised religion in itself fails to attract people. ${ }^{33}$

When religion has close ties to the state, it is regarded as an institution of power and not a representative of the people, especially the disadvantaged. For many, it becomes a quasi-public institution unworthy of trust. Generally, ties to the state prove damaging to religion. Religious autonomy and respect for the autonomy of other spheres of life constitute a modern state. If religion wishes to represent the public interest, it should distance itself from political institutions. Speaking of social, economic, and political matters, representatives of a religion should be careful not to raise suspicions of representing political interests. Close affinity to the state deprives religious actions of their legitimacy. ${ }^{34}$

Placing politics in the service of religion affects also the religious language, which has a peculiar nature. It is the language of revelations,

\footnotetext{
32 Cf. J. Tischner, W krainie schorowanej wyobraźni, op. cit., p. 48-49, 55-58, 210, 212-213.

33 Cf. H. Juros, Kościót. Kultura. Europa, op. cit., p. 118-120.

${ }^{34}$ Cf. J. Mariański, Sekularyzacja i desekularyzacja w nowoczesnym świecie, Lublin 2006, p. 62-63.
} 
deepest hopes, and the strongest loves. In the course of politicisation, it becomes the language of political activists who rely on imperative as their main form of expression. It aims to shape behaviours but cannot inspire beliefs. Its use divides people into enemies and allies. The tendencies to accuse, slander, suspect and judge are on the rise. The language of religion should be different, revolving around truth and appreciation of man rather than his degradation and exclusion. ${ }^{35}$

An interesting example of political religion of the former type is provided by a conservative movement called integrism, which opposes the enfeeblement of religious tradition, the adaptation of truths of the faith to the secularised world, and the separation of church and state. ${ }^{36}$ Integrists are incapable of dialogue, they sacralise state and nationalise religion, fail to see the ethical dimension of religion, base human dignity on the issue of beliefs, and attack freedom. Integrists cannot embrace a regime which grants equal rights to the "owners of the truth" and "owners of the untruth", forgetting that democracy is a model for resolving social conflicts in a pluralist society. In a democratic framework, conflict resolution should be achieved without violence and in full respect of the equality of rights shared by the citizens. Democracy creates the state of law, which is the common good shared by all citizens regardless of what they consider to be true. ${ }^{37}$

The latter form of political religion, far more common today, occurs as a result of the exploitation of religion as a political tool. Religion is used by politicians who, intent only on achieving their short-term goals, ignore its true purpose. It is an important challenge to protect religion against such designs. Otherwise it will be used in a manner inconsistent with its intents and purposes, depreciated as a spiritual force ${ }^{38}$ Nowadays, religion

35 Cf. J. Tischner, Nieszczęsny dar wolności, op. cit., p. 19, 23, 127-128, 193.

36 Cf. J. Gowin, Religia i ludzkie biedy..., op. cit., p. 113-116, 118.

37 Cf. J. Tischner, W krainie schorowanej wyobraźni, op. cit., p. 171, 187-188, 190-191, 202, 209, 211-212.

38 Cf. J. Pomianowski, Duchowa jedność Europy: nadzieje i lęki, in: Europa wspólnych wartości..., op. cit., p. 149-150. 
is often subject to criticism precisely for succumbing to exploitation at the hands of political factions. ${ }^{39}$

Instrumental use of religion is manifest especially in Islam, for separation of mosque and state does not exist in Muslim countries. ${ }^{40}$ However, an instrumental approach to religion may be observed in Christian countries as well. For instance, when it is necessary to further their careers, politicians may declare their adherence of the principles of Catholic social science, which, addressed to all "people of goodwill," has no party affiliation. ${ }^{41}$

In this context, the attitude of religion to political parties becomes an important practical matter, especially within the scope of forming alliances or developing close ties. It seems that religious institutions should not give in to the temptation of meddling in current political disputes. Importantly, religion should maintain a critical distance to politics and all parties intending to win its favour and support for their interests. ${ }^{42}$ Furthermore, religion cannot form political alliances precisely since it would require siding with a single party, while religion is universal. Since the term "party" is derived from the Latin word pars (part), it may be inferred that, by definition, a party represents the interest of only a part of the society. ${ }^{43}$ Thus, the use of religious adjectives to describe any party or political movements decreases the independence of religion from politics or parties. As a result, religion loses its universal character and enters the path of political ideologisation. The faithful of different party affiliations are brought against each other. Political adversaries are portrayed in religious terms, as if they were enemies of the faith. ${ }^{44}$

From the official and legal standpoint, religion has the right to involve itself in political struggles and form alliances with various factions. To decide otherwise would be a breach of the democratic principle of equality.

39 Cf. H. Juros, Kościót. Kultura. Europa, op. cit., p. 268.

40 Cf. J. Pomianowski, Duchowa jedność Europy..., op. cit., p. 150.

${ }^{41}$ Cf. J. Tischner, Nieszczęsny dar wolności, op. cit., p. 8, 127.

42 Cf. H. Juros, Kościót. Kultura. Europa, op. cit., p. 234-235.

43 Cf. M. Zięba, Kłopot za kłopotem..., op. cit., p. 148-149.

44 Cf. J. Tischner, Nieszczęsny dar wolności, op. cit., p. 125-126, 178. 
However, note that political struggle is incompatible with religious mission since the logic of state is the logic of coercion, whereas the logic of faith is the logic of freedom. Participation in the political struggle leads to ideologisation and instrumental use of religion. ${ }^{45}$

Thus, the participation in political life which requires a cooperation between religion and political parties proves quite risky. The threat of losing the faithful who do not share political inclinations of the religion in question must also be considered. Therefore, direct involvement in politics and an agreement with political factions is a measure of last resort, justified only in a situation of an infringement upon human rights. ${ }^{46}$ Even in that case, one cannot exclude the possibility that religion will be treated by political factions as a useful tool, only to be ultimately rejected and criticised.

\section{How to prevent the emergence of a political religion?}

Gowin emphasises that the emergence and continued existence of political religion may be prevented in the areas of politics and religion. In the political sphere, an amicable separation of church leadership and state authority is a must. In the religious sphere, apart from critically reflecting on the relationship between church and state, it is necessary to deepen the understanding of religion. ${ }^{47}$ Let us explore a few solutions to this problem.

Note that religion is brought into actuality throughout history and that, undoubtedly, it serves an important purpose in society. However, its mission must be carried out with great prudence. Therefore, religion must find its proper place in the pluralist society, accurately define the relationship between church and state, and specify the degree of their affinity and cooperation. ${ }^{48}$ One issue is particularly worth emphasising. Secular power and religious leadership must be separated and autonomous since they are bound by different rules and establish cooperation

45 Cf. J. Gowin, Kościót po komunizmie, op. cit., p. 59-60, 64-65.
46 Cf. J. Gowin, Religia i ludzkie biedy..., op. cit., p. 139-140.
${ }_{47}$ Cf. J. Gowin, Religia i ludzkie biedy..., op. cit., p. 122-123.
${ }_{48}$ Cf. H. Juros, Kościót. Kultura. Europa, op. cit., p. 121-122, 252. 
only for the common good. For such cooperation to exist, it is necessary to learn the art of dialogue and the ability of compromise. ${ }^{49}$ Note that dialogue may be a problematic issue for religion, especially in Poland, which escaped direct confrontation with the rationalist criticism of religion or the Protestant criticism of the Church. Thus, religious representatives face an important challenge of learning to stoutly defend their standpoints and to convince those who think differently. This is because dialogue must be based on exchanging rational arguments rather than passing judgements. ${ }^{50}$

Never forget that religion exists beyond politics and should not be affiliated with any political formation. According to Maciej Zięba, a Polish Dominican friar and a theoretician of social life, religion should be the "conscience" of the political world. In the name of defending values, this conscience should have the right to question politics while remaining neutral. Thus, the border between religion and politics is not to be crossed, especially as it escapes a clear definition. However, religion must remain free from political entanglements and be unambiguous and uncompromising. ${ }^{51}$

The differentiation between the public and political spheres is of the essence. Religion has a social dimension and builds a community. However, its public activity should not involve politics which is a peculiar sphere of public life. ${ }^{52}$ Yet, the presence of religion in social life cannot be opposed. All resistance in this respect stems from the belief that religion is a purely private matter. ${ }^{53}$ Nevertheless, the place of religion in the public sphere should be accepted since religion offers a space for debate and exchange of views among individuals holding varied opinions, including religious and philosophical beliefs which prove difficult to eradicate from discourse due to their significance in shaping all of human existence. 
Nevertheless, it should be emphasised that in a modern, liberal and democratic state, religion does not need to encompass all spheres of life and assert itself in a direct manner. It should be present in places where it is willingly accepted and treated as a vehicle for the fulfilment of one's life as a person. Thus, the right of people to adopt a non-religious lifestyle must be respected for both the "freedom of religion" and "freedom from religion" are the rights of man. The politicisation of religion quells its spiritual dimension. ${ }^{54}$

Even a certain confluence of values or goals cannot justify the identification of religion with any political formation. Otherwise, religion would end up being exploited for the purposes incompatible with its mission. Furthermore, at some point, a political alliance always requires religion to reach a compromise by bending its rules and to identify its teachings with a political programme. ${ }^{55}$ Therefore, for fear of losing its own identity, religion should appreciate and respect its own purposes and principles.

Since no systemic programme may be inferred from a religious doctrine, no political parties should be founded in the framework of religion. A religiously inspired party is a viable option, but that such a party does not claim to represent all the followers of the religion. However, any preferential alliance between religion and a specific political party is an impossibility. Religious representatives should rather focus on ingraining faith in the community and establishing a dialogue with politicians in the matters concerning values. In the area of politics in the strict sense, man needs to be free. ${ }^{56}$

Never forget that religion differs from ideology, which is a collection of ideas serving a specific socio-political programme. ${ }^{57}$ It should be emphasised that the fundamental task of religion involves the fulfilment

${ }^{54}$ Cf. T. J. Zieliński, Laicyzacja - sojusznik ewangelizacyjnej działalności Kościołów?, in: Sekularyzacja a ewangelizacja, red. Ł. Kamykowski, Kraków 2006, p. 78-81.

55 Cf. M. Zięba, Kłopot za kłopotem..., op. cit., p. 138.

${ }^{56}$ Cf. R. Buttiglione, Chrześcijanie a demokracja, tłum. zbior., Lublin 1993, p. 31-33.

57 Cf. J. Maritain, Człowiek i państwo, tłum. A. Grobler, Kraków 1993, p. 155-156; R. J. Neuhaus, Biznes i Ewangelia. Wyzwanie dla chrześcijanina-kapitalisty, tłum. B. Szlachta, Poznań 1993, p. 131-132. 
of a moral mission rather than direct participation in politics understood as the art of gaining power and ruling a state. Religion should take a stance with regard to socio-political life from a moral perspective. To achieve that, it should engage in a vigorous dialogue of partners with various parties and factions. However, religious officials cannot favour any party or preach the necessity to support a given government. Religion is concerned with moral order. In this respect, it is one of many entities criticised for their standpoints. ${ }^{58}$ According to an American expert on religion Philip Jenkins, distancing itself from any forms of politics and governmental interventions, no matter how well-intentioned they might be, makes religion flourish. ${ }^{59}$

To use the distinction made by Zięba, there are two spheres of the state: political and meta-political. The former includes political decisions, legal system, and social consensus. The latter concerns itself with moral norms and general philosophical assumptions. Religion may be present in both spheres but not simultaneously. It may exist at the level of politics. However, by doing so, it will place itself alongside other political factions. It may also choose to exist at the other level and limit itself to providing religious and moral advice. In the light of the nature and mission of religion, the other approach is more proper. ${ }^{60}$

Therefore, religion should content itself with "apolitical politics," which is the concern for the common good, because this approach will underscore its competence in matters of morality. ${ }^{61}$ Therefore, religion should: remind us that man is the primary subject and goal of all socio-political actions, emphasise the moral dimension of politics, and point to moral principles that should give us guidance. ${ }^{62}$

58 Cf. J. Mariański, Kościół katolicki w społeczeństwie obywatelskim..., op. cit., p. 81-82.

59 Cf. Ph. Jenkins, Chrześcijaństwo przyszłości. Nadejście globalnej Christianitas, tłum. S. Grodź, Warszawa 2009, p. 182.

${ }^{60}$ Cf. M. Zięba, Ale nam się wydarzyło..., op. cit., p. 315-320; M. Zięba, Chrześcijanie, polityka, ekonomia..., op. cit., p. 122-123; M. Zięba, Kłopot za kłopotem..., op. cit., p. 138; M. Zięba, Kościót wobec liberalnej demokracji, op. cit., p. 118-123, 149-151.

${ }^{61}$ Cf. J. Mariański, Kościót katolicki w społeczeństwie obywatelskim..., op. cit., p. 48.

62 Cf. Z. J. Zdybicka, Religia i polityka, op. cit., p. 119-120, 128. 
However, the best antidote to the phenomenon of political religion is the rebirth of the real religion which invokes transcendence and allows people to discover a true spirituality and a path leading to the fullness of life. ${ }^{63}$ Thus, the public presence of religion in the future should focus on providing a distinct spirituality to those who seek it rather than on exerting influence by other means, e.g. political. ${ }^{64}$ As a result, man will have an opportunity to enter into a relationship with the Absolute, and the religion itself will be capable of fulfilling its fundamental spiritual and saving function.

We ought to agree with Tomáš Halík, a Czech religious thinker, who believes that for religion, rescue will not come from the right or from the left, from the past or from the future, but from the depth within. Religion will best address the needs of the people if it is presented as a lifestyle marked with profound spirituality. ${ }^{65}$ Thus, further development of spirituality and a theological restoration are not only a programme for religion and a way of its transformation, but also a vital safeguard against the emergence of political religion.

\section{Conclusions}

The analysis presented above attempts to achieve two goals: firstly, to reveal the nature of religion itself, and secondly, to indicate some of the threats resulting from its politicisation and basic ways of preventing the emergence of a political religion. Thus, political religion involves a confusion of religion and politics. In the light of the above, it seems that the fundamental problem of political religion is the betrayal of its own nature and its fundamental saving function, while focusing on substitute political function.

${ }^{63}$ Cf. H. O. Seitschek, Mesjanizm polityczny i religia polityczna..., op. cit., p. 99.

${ }^{64}$ Cf. V. Possenti, Religia i życie publiczne. Chrześcijaństwo $w$ dobie ponowożytnej, tłum. T. Żeleźnik, Warszawa 2005, p. 277-278.

65 Cf. T. Halík, Noc spowiednika. Paradoksy małej wiary w epoce postoptymistycznej, tłum. A. Babuchowski, Katowice 2007, p. 147. 
Never forget that religion has its source in an experience of the transcendental dimension of the human life. Religion presupposes a relationship with the variously understood Absolute that gives meaning to the human existence and engages man in his entirety. The main goal of religion is to provide human life with meaning by initiating and maintaining that relationship. Its fundamental function is spiritual and saving. Therefore, preserving the identity of religion should be the object of concern. When this identity is lost, religion starts to focus on the functions (economic, educational, political, etc.), but, in the modern world, they can be fulfilled by civil society. Turning away from them enables religion to accomplish its fundamental mission. This approach seems valid especially in the light of the search for spiritual experiences by contemporary people and for very spiritual community.

In this context, all attempts at ideologisation, and politicisation in particular, are a grave threat for religion since they enfeeble its supernatural dimension and drive people away. Religion is consequently used in a manner inconsistent with its intents and purposes, depreciated as a spiritual force of man. The exploitation of religion begins. Its official representatives must acknowledge the inevitability of far-reaching compromises. As a result, religion is regarded an institution unworthy of trust. And if religion fails to meet expectations, it appears the possibility of being rejected and singled out for fierce criticism.

Preventing the emergence and continued existence of political religion is an important challenge which should be tackled in the areas of politics and religion. Within the scope of the former, it is necessary to ensure that the identity of religion is respected, and that religion has its proper place in the society. It is important to strive for the rebirth of an authentic religion which becomes a source of spirituality.

Religion should distance itself from political factions and establish rules for cooperation with the state, which depend on the specificity of a given state. Church leadership and political authority should be separated. It seems that politicians will always remain driven by the short-terms interests of their parties. As such, they will never stop attempting to exploit citizens and various social groups, including religious communities. 
Therefore, a greater common sense and responsibility should be expected from the official representatives of religion. Out of concern for the spiritual and moral authority of religion and the fulfilment of its fundamental functions, they should not succumb to manipulation or involve themselves with political affairs, especially as those dealings are not necessarily concerned with the good of the people but with the acquisition and preservation of power.

Both politicians and religious leaders should be aware of that fact and strive to preserve the specific character of state and religion, which have different sources, nature and goals. It may, therefore, raise doubts about the religious setting of all state ceremonies, as a result of which religious rites often lose their spiritual dimension and become only a form of pure decoration. Improper practice are also speeches of politicians during the sacramental acts. They make an occasion for political rally and agitation than for establishing a relationship with God. Not to mention the fact that instead of building unity, they create scandalous divisions among the faithful, who can sympathize with various political factions.

The distinction should be made between political and public spheres. Simultaneously, let us emphasise that religion cannot be eradicated from the public sphere and reduced only to the private one, for it has a crucial moral mission in the public sphere. Educational activity of religious institutions should lead men to accept moral values that shape them as citizens and ensure the moral character of civil society. Religion is also one of the participants in the debate on the common good. Therefore, it should be active in the meta-political sphere.

The temptation of political religion may be found at virtually every moment of history and in all political regimes. It is also well-known to political activists in a liberal democracy, who attach great importance to the postulate of autonomy and amicable cooperation between church and state. However, never forget that liberal democracy is a political project intended to ensure that people of various beliefs can lead a harmonious and peaceful life in a single country. Thus, its concept envisions no official religion, although the relationship between church and state may be formed in accordance with one of many possible models. 


\section{Bibliography}

Buttiglione R., Chrześcijanie a demokracja, tłum. zbior., Lublin 1993.

Giddens A., Nowoczesność i tożsamość. „Ja” i społeczeństwo w epoce późnej nowoczesności, tłum. A. Szulżycka, Warszawa 2012.

Gowin J., Kościół po komunizmie, Kraków 1995.

Gowin J., Religia i ludzkie biedy. Ks. Tischnera spory z Kościołem, Kraków 2003.

Halík T., Noc spowiednika. Paradoksy małej wiary w epoce postoptymistycznej, tłum. A. Babuchowski, Katowice 2007.

Jenkins Ph., Chrześcijaństwo przyszłości. Nadejście globalnej Christianitas, tłum. S. Grodź, Warszawa 2009.

Juros H., Kościót. Kultura. Europa, Lublin-Warszawa 1997.

Luhmann N., Funkcja religii, tłum. D. Motak, Kraków 2007.

Mariański J., Kościół katolicki w społeczeństwie obywatelskim. Refleksje socjologiczne, Lublin 1998.

Mariański J., Sekularyzacja i desekularyzacja w nowoczesnym świecie, Lublin 2006.

Maritain J., Człowiek i państwo, tłum. A. Grobler, Kraków 1993.

Neuhaus R. J., Biznes i Ewangelia. Wyzwanie dla chrześsijanina-kapitalisty, tłum. B. Szlachta, Poznań 1993.

Pomianowski J., Duchowa jedność Europy: nadzieje i lęki, in: Europa wspólnych wartości. Chrześcijańskie inspiracje w budowaniu zjednoczonej Europy, red. S. Zięba, Lublin 2004, p. 147-150.

Possenti V., Religia i życie publiczne. Chrześcijaństwo w dobie ponowożytnej, tłum. T. Żeleźnik, Warszawa 2005.

Prostak R., Teista $w$ demoliberalnym świecie. Rzecz o amerykańskich rozważaniach wokót rozumnej polityki, Kraków 2014.

Religia polityczna, http://www.newsweek.pl/europa/religia-polityczna,45280,1,1.html (2.12.2017).

Seitschek H. O., Mesjanizm polityczny i religia polityczna - niemieckie interpretacje uniwersalnego zjawiska, tłum. M. Kurkowska, „Teologia Polityczna” 4 (2006-2007), p. 96-107.

Tillich P., Dynamika wiary, tłum. A. Szostkiewicz, Poznań 1987.

Tillich P., Pytanie o Nieuwarunkowane. Pisma z filozofii religii, tłum. J. Zychowicz, Kraków 1994. 
Tischner J., Filozofia dramatu, Paryż 1990.

Tischner J., Myślenie wedtug wartości, Kraków 1982.

Tischner J., Nieszczęsny dar wolności, Kraków 1996.

Tischner J., Spór o istnienie człowieka, Kraków 1998.

Tischner J., W krainie schorowanej wyobraźni, Kraków 1998.

Zawada M., Wartości duchowe w kulturze postmoderny, in: Europa wspólnych wartości.

Chrześcijańskie inspiracje w budowaniu zjednoczonej Europy, red. S. Zięba, Lublin 2004, p. 158-169.

Zdybicka Z. J., Człowiek i religia. Zarys filozofii religii, Lublin 1993.

Zdybicka Z. J., Religia i polityka, „Człowiek w Kulturze” 3 (1994), p. 111-132.

Zieliński T. J., Laicyzacja - sojusznik ewangelizacyjnej działalności Kościołów?, in:

Sekularyzacja a ewangelizacja, red. Ł. Kamykowski, Kraków 2006, p. 77-87.

Zięba M., Ale nam się wydarzyło. O papieżu i Polsce, Kościele i świecie, Poznań 2013.

Zięba M., Chrześcijanie, polityka, ekonomia: prawdy i kłamstwa, Kraków 2003.

Zięba M., Demokracja i antyewangelizacja: komentując nauczanie Jana Pawła II, Poznań 1997.

Zięba M., Epoka Jana Pawła II. Zrozumieć niezwykły pontyfikat, Poznań-Kraków 2006. Zięba M., Kłopot za kłopotem. Katolik w dryfującej Europie, Poznań 2015.

Zięba M., Kościót wobec liberalnej demokracji, in: M. Novak, A. Rauscher, M. Zięba,

Chrześcijaństwo, demokracja, kapitalizm, tłum. W. Büchner, Poznań 1993, p. 111-153. Zięba M., Papieże i kapitalizm, Kraków 1998.

Zięba M., Po szkodzie? Przed szkodą? O Polsce, kapitalizmie i kontemplacji, Kraków 1996.

\section{Abstract}

\section{The Problem of Political Religion}

The author of the article addressed the issue of the fundamental problem of religion, which is embezzlement of its basic spiritual (saving) function and focus on the implementation of substitute functions, especially in the area of politics. Its expression is the emergence of a political religion, understood as a form of placing politics in the service of religion or religion in the service of politics. The article has been divided into three 
parts, which present the nature of religion itself (1), selected threats related to its politicization (2) and the basic ways of preventing the emergence and maintenance of political religion (3).

\section{Keywords}

nature and functions of religion, form of political religion, principles of the coexistence of religion and the state

\section{Abstrakt}

\section{Problem religii politycznej}

Autor artykułu podjął kwestię fundamentalnego problemu religii, którym jest sprzeniewierzenie się swej podstawowej funkcji duchowej (zbawczej) i skoncentrowanie się na realizacji funkcji zastępczych, zwłaszcza w obszarze polityki. Jej wyrazem jest powstanie religii politycznej, rozumianej jako forma umieszczania polityki w służbie religii lub religii w służbie polityki. Artykuł został podzielony na trzy części, w których przedstawiono naturę samej religii (1), wybrane zagrożenia związane z jej upolitycznieniem (2) oraz podstawowe sposoby zapobiegania powstawaniu i utrzymaniu religii politycznej (3).

\section{Słowa kluczowe}

natura i funkcje religii, formy religii politycznej, zasady współistnienia religii i państwa 